\title{
EFFECT OF RHIZOBIUM ON GROWTH OF DIFFERENT MUNGBEAN VARIETIES UNDER SALT STRESS CONDITIONS
}

\author{
Muhammad Arshad Ullah ${ }^{1}$, Raheel Baber ${ }^{1}$, Syed Ishtiaq Hyder ${ }^{1}$, Tariq Sultan ${ }^{1}$, Imdad Ali Mahmood ${ }^{1}$ and \\ Kaleem Ullah ${ }^{2}$ \\ ${ }^{1}$ National Agricultural Research centre, Islamabad. Pakistan. $45500 .{ }^{2}$ Faculty of Agriculture, Gomal University, \\ Dera Ismail Khan, KPK, Pakistan.
}

Corresponding author: Muhammad Arshad Ullah Email: arshadullah1965@gmail.com

\begin{abstract}
Excessive and imbalanced use of chemical fertilizers may pose devastating effect on soil fertility and sustainable productivity. Bio-organic amendments improve soil fertility and sustainable crop productivity. Seeds of mungbean varieties i.e. NCM-2013, Chackwal-Mung 06, NM-11 and AZRI-06 were inoculated with rhizobium in saline soil. These inccilated miunngbean varieties were sown under artificially salinity developed soil $\left(E C e=5.0 \mathrm{dSm}^{-1}\right)$ using completely randomized design with three repeats for enhancement of growth. The experiment was conducted during July to September, 2015 in the Head House of Land Resources Research Institute, National Agricultural research Centre, Islamabad, Pakistan. Data were collected on germination, plant height, root length, fresh / dry weight and chlorophyll contents during experiment period. Ionic concentrations of $\mathrm{P}, \mathrm{Cu}, \mathrm{Fe}, \mathrm{Mg}$ and $\mathrm{Zn}$ were determined to compare the difference of edible quality in saline soil under the inoculation of seeds with rhizobium. Effect of biozote on germination, root length, fresh weight and dry weight was significant in all mung bean varieties: NCM-2013, Chakwal Mung-06, NM-II and AZRI-06 under salt stress conditions. Maximum germination (53\%) was recorded by Chakwal Mung- 06 followed by $51 \%$ by AZRI-06. The maximum root length $(10.1 \mathrm{~cm})$ was registered by NM-II. Fresh weight / plant was maximum $(5.1 \mathrm{~g})$ by AZRI-06. The maximum dry weight/plant $(1.5 \mathrm{~g})$ was recorded by AZRI-06. Maximum P\% (0.14), Cu (4.83 ppm), Fe (179.3ppm), Mg (2.07ppm) and $\mathrm{Zn}$ (168.8ppm) of Chakwal Mung-06 with the use of rhizobium under salt stress by NM-11. Similar trend was also recorded in ionic concentration of $\mathrm{P}, \mathrm{Cu}, \mathrm{Fe}$ and $\mathrm{Mg}$ by NM-11 without rhizobium under salt stress conditions.. The saline soil affected the quality of mungbean showing the reduction under salt stress without rhizobium inoculation in ionic concentration. The results of ionic values showed that NM-11 attained the highest position following the AZRI-06. [3] and [8] reported same results regarding $\mathrm{K}$ and $\mathrm{P}$ of different crops under salt stress conditions.
\end{abstract}

\section{Key Words--- Mungbean varieties, saline soil, rhizobiumgrowth, edible quality and ionic concentration INTRODUCTION}

Biofertilizers are known to play an important role in increasing biological fixation of atmospheric nitrogen and enhance phosphorus availability to crop (Bhat et al., 2013). Similarly humus derived from vermicompost is most commonly used for sustainable production (Premsekhar and Rajashree 2009) due to its beneficial effects on nutrient uptake and retention, pest control and productivity (Barrios et al., 2011).

Mungbean is a very important pulse crop which provides an inexpensive source of vegetable dietary protein. In Pakistan, mungbean is cultivated on an area of 127.7 thousand hectares with total grain production of 98.7 thousand tons Economic survey of Pakistan, 15). It is popular for its nutritive value and digestibility, containing higher protein contents (30\%), fat

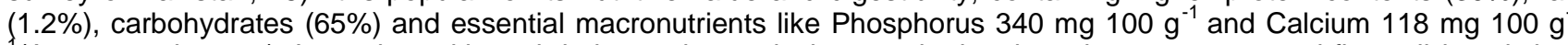
(Anwar et al., 2007). It can be cultivated during spring and winter and takes less time to mature and fits well in existing cropping pattern of the country. Today, of various abiotic stresses, soil salinity is known to cause considerable crop losses (Ashraf et al., 2008). Although soil salinity occurs predominantly in arid and semiarid regions, it has been found in all the climatic zones (Munns, 2008). Moreover, the problem in salt affected land is increasing due to low quality water usage for irrigation, improper drainage in canal-irrigated wetland agro-ecosystems, entry of seawater in coastal areas during cyclones, and higher accumulation of salts in the root zone due to considerable evaporation of water and insufficient leaching of ions due to low rainfall in arid and semi-arid regions (Munns, 2008). According to an estimate, 33\% of irrigated land world-wide has been affected by salinity (Ashraf et al., 2008). Pakistan is worst hit by soil salinity as about $14 \%$ of total irrigated land in Pakistan is salt affected (Economic Survey of Pakistan, 2008). Salt affected soils are generally categorized as saline, sodic, or saline-sodic. In other words, a soil is considered to be saline when electrical conductivity of saturate soil pastes is equal or greater than $\sim 4 \mathrm{dS} \mathrm{m}-1$ at $25^{\circ} \mathrm{C}$ (equivalent to $\sim 40 \mathrm{mM} \mathrm{NaCl}$ ) and the sodium adsorption ratio (SAR) is $\sim 13-15$ (Munns, 2008).

Inside the plant, soluble salts at higher concentrations cause hyperosmolality, ion toxicity and disequilibrium of nutrients that adversely affect plant growth and development (Munns, 2008). High levels of both $\mathrm{Na}+$ and $\mathrm{Cl}$ - in cytosol are inhibitory to a number of metabolic and cellular processes (Ashraf, 2009).

Soil salinity causes prominent losses of yield in all crops, therefore causing to reduction in crop production (Ashraf,. 2009 and Cha-um. et al., 2011). Reduction in yield due to salinity is due to a number of physiological and biochemical abnormalities in plants grown which have been mentioned in a number of comprehensive reviews on salinity effects and tolerance in plants (Ashraf et al., 2008, Munns, 2008, Jamil et al., .2011, and Krasensky and Jonak,. 2012). Researchers have been struggling for the last many decades to solve this issue by conducting a variety of experiments. 
The conductance of such experiments has resulted in a substantial increase in both growth and yield of many crops grown under saline conditions (Ashraf,. 2009 and Cha-um. et al., 2011)Exogenous application of inorganic essential nutrients as foliar spray or through the root growing medium has also been reported to be an economical and efficient means of mitigating the adverse effects of salt stress on different crops (Ashraf,. 2009 and Kaya . et al., 2010) of different major essential nutrients, potassium $(K)$ and phosphorus $(P)$ play vital roles in plant growth and regulate various metabolic reactions (Taiz and Zeigr, 2010).. Therefore this study was carried out to evaluate the performance of mungbean varieties under saline condition for the enhancement of pulse production under marginal lands.

\section{MATARIALS AND METHODS}

Seeds of mungbean varieties i.e. NCM-2013, Chackwal-Mung 06, NM-11 and AZRI-06 were inoculated with rhizobium in saline soil. These inccilated miunngbean varieties were sown under artificially salinity developed soil $\left(E C e=5.0 \mathrm{dSm}{ }^{-1}\right)$ using completely randomized design with three repeats for enhancement of growth. The experiment was conducted during July to September, 2015 in the Head House of Land Resources Research Institute, National Agricultural research Centre, Islamabad, Pakistan. Data were collected on germination, plant height, root length, fresh / dry weight and chlorophyll contents during experiment period. Ionic concentrations of $\mathrm{P}, \mathrm{Cu}, \mathrm{Fe}, \mathrm{Mg}$ and $\mathrm{Zn}$ were determined to compare the difference of edible quality in saline soil under the inoculation of seeds with rhizobium. The data collected were analyzed statistically according to the procedure given using statistic, 2000 package and means between treatments were compared using LSD test at 5\% probability level ( Steel and Torrie, 1997)

\section{RESULTS AND DISCUSSION}

Effect of biozote on germination, root length, fresh weight and dry weight was significant in all mung bean varieties: NCM2013, Chakwal Mung-06, NM-11 and AZRI-06 under salt stress conditions (Table-1). Maximum germination (53\%) was recorded by Chakwal Mung-06 followed by $51 \%$ by AZRI-06. The maximum root length $(10.1 \mathrm{~cm})$ was registered by NM-II. Fresh weight / plant was maximum $(5.1 \mathrm{~g})$ by AZRI-06. The maximum dry weight/plant $(1.5 \mathrm{~g})$ was recorded by AZRI-06. . These results are agreed with the findings of (Ashraf et al., 2008, Munns, 2008, Jamil et al., .2011,and Krasensky and Jonak,. 2012). Maximum P\% (0.14), Cu (4.83 ppm), Fe (179.3ppm), Mg (2.07ppm) and Zn (168.8ppm) of Chakwal Mung06 with the use of rhizobium under salt stress by NM-11. Smilar trend was also recorded in ionic concentration of $P$, Cu, $\mathrm{Fe}$ and Mg by NM-11 without rhizobium under salt stress conditions. (Table-2). The saline soil affected the quality of mungbean showing the reduction under salt stress without rhizobium inoculation in ionic concentration. The results of ionic values showed that NM-11 attained the highest position following the AZRI-06. Ashraf et al., 2008 Akram et al.,. 2009 and Taiz and Zeigr, 2010) reported same results regarding $\mathrm{K}$ and $\mathrm{P}$ of different crops under salt stress conditions.

\section{REFERENCES}

1. Akram MS, Ashraf M and Akram NA. 2009. Effectiveness of potassium sulfate in mitigating salt-induced adverse effects on different physio-biochemical attributes in sunflower (Helianthus annuus L.). Flora 204: $471-483$

2. Anwar, F., S. Latif, R. Przybylski, B. Sultana and M. Ashraf. 2007. Chemical composition and antioxidant activity of seeds of different cultivars of mungbean. J. Food Sci., 72(7): 503-510.

3. Ashraf M. 2009. Biotechnological approach of improving plant salt tolerance using antioxidants as markers. Biotech Adv. 27: 84-93

4. Ashraf M, Athar HR, Harris PJC and Kwon TR. 2008. Some prospective strategies for improving crop salt tolerance. Adv Agron. 97: 45-110].

5. Barrios-Masias, F.H., Cantwell, M.I. and Jackson, L.E. (2011) Cultivar Mixtures of Processing Tomato in an Organic Agroecosystem. Organic Agriculture, 1, 17-30.

6. Bhat, T.A., Gupta, M., Ganai, M.A., Ahanger, R.A. and Bhat, H.A. (2013) Yield, Soil Health and Nutrient Utilization of Field Pea (Pisum sativum L.) as Affected by Phosphorus and Biofertilizers under Subtropical Conditions of Jammu.International Journal of Modern Plant and Animal Science, 1, 1-8

7. Cha-um S, Pokasombat $Y$ and Kirdmanee C. 2011. Remediation of salt-affected soil by gypsum and farmyard manure - Importance for the production of Jasmine rice. Aust J Crop Sci. 5: 458-465.

8. Economic Survey of Pakistan, 2008.Government of Pakistan.p.145.

9. Economic Survey of Pakistan, 2015...Government of Pakistan.p.222.

10. Jamil A, Riaz S, Ashraf M and Foolad MR. 2011. Gene expression profiling of plants under salt stress. Crit Rev Plant Sci 30: 435-458

11. Kaya C, Tuna AL and Okant AM. 2010. Effect of foliar applied kinetin and indole acetic acid on maize plants grown under saline conditions. Turk J Agr For 34: 529-538.

12. Krasensky J and Jonak C. 2012. Drought, salt, and temperature stress-induced metabolic rearrangements and regulatory networks. J Exp Bot. 63: 1593-1608

13. Munns R, Tester M 2008. Mechanisms of salinity tolerance. Annu Rev Plant Biol., 59: 651-681

14. Premsekhar, M. and Rajashree, V. (2009) Influence of Organic Manures on Growth, Yield and Quality of Okra. American-Eurasian Journal of Sustainable Agriculture, 3, 6-8.

15. Steel, R.G.D. and J.H. Torrie,, 1997. Principles and Procedure of Statistics. McGraw Hill Book Co., Inc. Singapore, pp: 173-177.

16. Taiz L and Zeiger E. 2010. Plant Physiology, Sinecure Associates, Inc. Publishers, Sunderland, Massachusetts, p.782. 
Table; 1 Effect of biozote on Growth of Mungbean varieties under saline conditions

\begin{tabular}{|c|c|c|c|c|c|c|c|c|c|c|c|c|}
\hline \multirow{2}{*}{$\begin{array}{l}\text { Mung } \\
\text { bean } \\
\text { Varietie } \\
\text { s }\end{array}$} & \multicolumn{2}{|c|}{$\begin{array}{l}\text { Germination } \\
(\%)\end{array}$} & \multicolumn{2}{|c|}{$\begin{array}{l}\text { Shoot height } \\
(\mathrm{cm})\end{array}$} & \multicolumn{2}{|c|}{$\begin{array}{l}\text { Root } \\
\text { length } \\
\text { (cm) }\end{array}$} & \multicolumn{2}{|c|}{$\begin{array}{l}\text { Fresh } \\
\text { weight }^{\text {plant }}{ }^{-1}(\mathrm{gm})\end{array}$} & \multicolumn{2}{|c|}{$\begin{array}{l}\text { Dry weight plant } \\
\text { (gm) }\end{array}$} & \multicolumn{2}{|c|}{$\begin{array}{l}\text { Chlorophyll } \\
\text { Contents (\%) }\end{array}$} \\
\hline & $\begin{array}{l}- \\
\text { Biozo } \\
\text { te }\end{array}$ & $\begin{array}{l}+ \\
\text { Bio } \\
\text { zote }\end{array}$ & $\begin{array}{l}- \\
\text { Bioz } \\
\text { ote }\end{array}$ & $\begin{array}{l}+ \\
\text { Bioz } \\
\text { ote }\end{array}$ & $\begin{array}{l} \\
\text { Bio } \\
\text { zote }\end{array}$ & $\begin{array}{l}+ \\
\text { Bio } \\
\text { zote }\end{array}$ & $\begin{array}{l}- \\
\text { Bioz } \\
\text { ote }\end{array}$ & $\begin{array}{l}+ \\
\text { Bio } \\
\text { zote }\end{array}$ & Biozote & $\begin{array}{l}+ \\
\text { Biozot } \\
\text { e }\end{array}$ & $\begin{array}{l}- \\
\text { Biozo } \\
\text { te }\end{array}$ & $\begin{array}{l}+ \\
\text { Biozot } \\
\text { e }\end{array}$ \\
\hline $\begin{array}{l}\text { NCM- } \\
2013\end{array}$ & $40 \mathrm{~b}$ & $50 a$ & 11.1 & 12.1 & $6.3 b$ & $8.1 a$ & $\begin{array}{l}3.4 a \\
b\end{array}$ & $4.2 a$ & $0.8 \mathrm{c}$ & $1.2 \mathrm{a}$ & 24.3 & $24.8 \mathrm{c}$ \\
\hline $\begin{array}{l}\text { Chack } \\
\text { wal- } \\
\text { Mung } \\
06\end{array}$ & $45 a b$ & $53 a$ & 10.2 & 9.9 & $6.0 \mathrm{~b}$ & $8.2 a$ & $\begin{array}{l}3.1 \mathrm{a} \\
\mathrm{b}\end{array}$ & $4.5 a$ & $0.6 c$ & $1.1 b$ & 23.1 & $22.9 c$ \\
\hline NM-11 & $36 \mathrm{~b}$ & $45 a$ & 9.5 & 11.5 & $8.2 a$ & $\begin{array}{l}10.1 \\
a\end{array}$ & $3.3 \mathrm{~b}$ & $4.0 \mathrm{~b}$ & $0.5 \mathrm{c}$ & $1.0 b$ & 24.3 & 25.1bc \\
\hline $\begin{array}{l}\text { AZRI- } \\
06\end{array}$ & $42 a b$ & $51 a$ & 11.7 & 10.7 & $5.5 \mathrm{c}$ & $6.5 \mathrm{c}$ & $\begin{array}{l}3.6 \mathrm{a} \\
\mathrm{b}\end{array}$ & $5.1 a$ & $0.9 b c$ & $1.5 a$ & 24.6 & 23.2c \\
\hline LSD & 12 & & NS & & 2.4 & & 1.1 & & 0.4 & & NS & \\
\hline
\end{tabular}

Table; 2 Effect of biozote on ionic concentration of Mungbean varieties under saline conditions

\begin{tabular}{|c|c|c|c|c|c|c|c|c|c|c|}
\hline \multirow{2}{*}{$\begin{array}{l}\text { Mung } \\
\text { bean } \\
\text { Varieties }\end{array}$} & \multicolumn{2}{|l|}{$\begin{array}{l}P \\
(\%)\end{array}$} & \multicolumn{2}{|l|}{$\begin{array}{l}\text { Cu } \\
\text { (ppm) }\end{array}$} & \multicolumn{2}{|l|}{$\begin{array}{l}\text { Fe } \\
(\mathrm{ppm})\end{array}$} & \multicolumn{2}{|l|}{$\begin{array}{l}\mathrm{gg} \\
(\mathrm{ppm})\end{array}$} & \multicolumn{2}{|l|}{$\begin{array}{l}\text { Zn } \\
(\mathrm{ppm})\end{array}$} \\
\hline & $\begin{array}{l}-\overline{\text { Biozot }} \\
\mathrm{e}\end{array}$ & $\begin{array}{l}+ \\
\text { Biozot } \\
\text { e }\end{array}$ & $\begin{array}{l}\overline{-} \\
\text { Biozot } \\
\text { e }\end{array}$ & $\begin{array}{l}+ \\
\text { Biozo } \\
\text { te }\end{array}$ & Biozote & $\begin{array}{l}+ \\
\text { Biozot } \\
\text { e }\end{array}$ & $\begin{array}{l}\text { Biozot } \\
\text { e }\end{array}$ & $\begin{array}{l}+ \\
\text { Biozot } \\
\text { e }\end{array}$ & $\begin{array}{l}\text { Biozot } \\
\text { e }\end{array}$ & $\begin{array}{l}+ \\
\text { Biozot } \\
\text { e }\end{array}$ \\
\hline NCM-2013 & 0.06 & 0.12 & 2.62 & 3.12 & 140.3 & 176.4 & 1.72 & 1.82 & 100.4 & 152.7 \\
\hline $\begin{array}{l}\text { Chackwal } \\
\text {-Mung } \\
06\end{array}$ & 0.07 & 0.11 & $\begin{array}{l}3 \\
.14\end{array}$ & 3.94 & 142.4 & 162.4 & 1.25 & 1.62 & 105.6 & 142.3 \\
\hline NM-11 & 0.06 & 0.14 & 2.26 & 4.83 & 139.4 & 179.3 & 1.85 & 2.07 & 99.8 & 168.8 \\
\hline AZRI-06 & 0.03 & 0.12 & 3.98 & 4.33 & 142.6 & 165.2 & 1.47 & 1.78 & 109.1 & 155.4 \\
\hline
\end{tabular}

